logos_i_ethos_2019_2_(50), s. 199-216

DOI: http://dx.doi.org/10.15633/lie.3485

Ewa Laskowska

https://orcid.org/0000-0002-5924-0506

Uniwersytet Papieski Jana Pawła II w Krakowie

\title{
Pozytywne implikacje myśli Fryderyka Nietzschego dla chrześcijaństwa post mortem Dei. Próba analizy
}

W obecnych czasach pytania o Boga i człowieczeństwo, które wciąż brzmią na ruinach świata wewnętrznie zniszczonego pożogą wojen, pozostają otwarte. Podjęcie ich wydaje się jednym z kluczowych zadań, ponieważ istnieje ryzyko, że nieustannie uciekając od odpowiedzi człowiek, będzie pogrążał się w coraz wymyślniejsze środki mające znieczulić poczucie bezsensu istnienia ${ }^{1}$. Dlatego konieczny jest powrót do poszukiwania prawdziwego Boga, stawiania pytań o Boga i mówienia o Bogu, by w nocy świata - jak pisał Heidegger, odnaleźć Boga Abrahama, Izaaka i Jakuba - Boga Ewangelii.

Czy w myśli „pierwszego filozofa obecnej epoki”2 można odnaleźć wskazówki, jaką drogą należy kroczyć w najciemniejszych godzinach nocy, która nastała post mortem Dei? Czy myślenie Nietzschego

1 Por. F. Chirpaz, Sprzeczności posttotalitarnego czasu, przeł. M. Chłopecki, „Znak” 45 (1993) nr 458 (7), s. 139.

${ }^{2}$ K. Löwith, Od Hegla do Nietzschego. Rewolucyjny przełom w myśli XIX wieku, przeł. S. Gromadzki, Warszawa 2001, s. 231.
Ewa Laskowska - magisterium uzyskała na Wydziale Teologicznym Uniwersytet Papieskiego Jana Pawła II w Instytucie im św. Jana Kantego w Bielsku-Białej na podstawie pracy: Sposoby rozumienia frazy Fryderyka Nietzschego „Bóg umarl'. Obecnie doktorantka Wydziału Teologii Uniwersytetu Papieskiego Jana Pawła II w Krakowie. Prowadzi interdyscyplinarne badania z zakresu teologii i filozofii nad racjonalnością wiary w ujęciu Gilberta Keitha Chestertona. 
może - paradoksalnie - stać się szlakiem w poszukiwaniu niepojętego Boga? Czy myśl Nietzscheańska jest tak sprzeczna z chrześcijaństwem, jak się powszechnie sądzi?

Próba odpowiedzi na powyższe pytania wymaga analizy i zestawienia wielu materiałów źródłowych i komentarzy. Ze znacznej liczby opracowań na temat myśli Fryderyka Nietzschego wybrane zostały dzieła najważniejsze dla podejmowanego zagadnienia.

Analiza myśli Nietzscheańskiej została dokonana w kontekście współczesnego świata i chrześcijaństwa. Wskazuje ona na niezwykłą aktualność myśli Nietzschego, nie tylko wtedy, gdy opisuje ona i wieści negatywne przemiany, do jakich doszło w świecie, ale nade wszystko gdy ukazuje możliwości wyjścia $z$ tej negatywnej sytuacji. Punkt wyjściowy rozważań stanowi konstatacja „Bóg umarł”, która określa sytuację dzisiejszych czasów, następnie rozważony zostanie postchrześcijański nihilizm, koncepcja człowieka oraz życia, by w prorockich diagnozach Nietzschego szukać nieoczywistych wskazówek.

\section{1. Śmierć Boga we współczesnym świecie}

Jednym z najbardziej znanych fragmentów pism Nietzschego pozostaje passus, w którym ustami szaleńca/błazna ${ }^{3}$ głosi on wydarzenie śmierci Boga ${ }^{4}$. Filozof, podając w swych dziełach różne przyczyny śmierci Boga ${ }^{5}$, w Wiedzy radosnej winą za zbrodnie zabicia Boga obarcza ludzi ${ }^{6}$. Bóg umarł, a my ponosimy za to odpowiedzialność, cóż z tym zrobimy? Pytanie to jest dla Nietzschego niezwykle istotne, ponieważ śmierć Boga

3 Por. T. Halik, Cierpliwość wobec Boga. Spotkanie wiary z niewiara, przeł. A. Babuchowski, Kraków 2011, s. 121, 185.

4 Zob. F. Nietzsche, Wiedza radosna, przeł. L. Staff, Kraków 2003, s. 110-111.

5 Zob. F. Nietzsche, Tako rzecze Zaratustra. Ksiażka dla wszystkich i dla nikogo, przeł. W. Beret, Warszawa 1990, s. 321 - śmierć Boga z litości; s. 323 - wielorakość śmierci bogów; s. 326 - morderstwo na świadku.

${ }^{6}$ Zob. F. Nietzsche, Wiedza radosna, dz. cyt., s. 111. Refleksja nad owym lapidarnym stwierdzeniem „Bóg umarł” otwiera szeroki horyzont możliwości jego interpretacji. Autor ze względu na tematykę niniejszego artykułu odnosi się jedynie do interpretacji przedstawiającej śmierć Boga jako odrzucenie Boga przez ludzi w każdej sferze życia. 
stanowi wydarzenie o ogromnym znaczeniu i konsekwencjach ${ }^{7}$. Prorocko przewidywał on skutki, jakie pociąga za sobą śmierć Boga. Pisał w Ecce homo: „Przy tym wszystkim jestem z konieczności także człowiekiem złowieszczym. Bowiem gdy prawda zetrze się z kłamstwem tysiącleci, nastąpią przewroty, zatrzęsie się ziemia, przeniosą się góry i doliny, że nawet o czymś podobnym nie śniono. Pojęcie polityki rozpłynie się w wówczas całkiem w wojnie duchów, wszystkie potężne twory starej społeczności wysadzone zostaną w powietrze - wszystkie spoczywają na kłamstwie: nastaną wojny, jakich jeszcze nie było na ziemi" ${ }^{8}$. Na wypełnienie Nietzscheańskich słów nie trzeba było długo czekać. Zaledwie kilkadziesiąt lat później przyszło ludziom doświadczyć konsekwencji zbagatelizowanego wydarzenia ${ }^{9}$. Odrzucenie Boga i ekspansja człowieka próbującego zapełnić opustoszałe po Nim miejsce lub wręcz samemu je zająć zaowocowały wojnami na niespotykaną dotąd skalę, które przetoczyły się przez ziemię, pozostawiając spustoszenie tak w świecie, jak i w człowieku. Ogrom tych wojen i zmiany, jakie przyniosły, wpłynęły na fakt, iż zaczęto doszukiwać się momentu skonania Boga właśnie w okropnościach II wojny światowej. Podnosiły się głosy pytające: „gdzie był Bóg?", zaczęto się zastanawiać, jak możliwa jest wiara po Kołymie czy Oświęcimiu $^{10}$. Gdy jednak nie potrafiono znaleźć odpowiedzi, wydaje się, iż z czasem zarzucono ich szukania, a człowiek stopniowo pogrążał się - w obecnie powszechnie panującej - konsumpcji i bezmyślności.

$\mathrm{Na}$ gruncie protestanckim podjęto próby wypracowania założeń teologii śmierci Boga ${ }^{11}$ oraz przedstawiono koncepcje bezreligijnego chrześcijaństwa, w którym Bóg pozostaje zasłonięty ciemnością

7 Por. L. Szestow, Potestas clavium, przeł. J. Chmielewski, Kęty 2005, s. 19.

8 F. Nietzsche, Ecce homo. Jak stajemy się tym, czym jesteśmy, przeł. L. Staff, Kraków 2003, s. $74-75$.

9 Por. M. Neusch, U źródeł współczesnego ateizmu. Sto lat dyskusji na temat Boga, przeł. A. Turowiczowa, Paris 1980, s. 147.

10 Por. esej: J. Tischner, Opisując sytuacje polskiej wiary, w: J. Tischner, Idąc przez puste błonia, Kraków 2005, s. 119-134 oraz T. Halik, Wzywany czy niewzywany Bóg się tutaj zjawi, przeł. A. Babuchowski, Kraków 2006, s. 92-93.

11 Por. P. Sokołowski, Śmierć Boga. Teologia, w: Encyklopedia katolicka, t. 19, red. E. Gigilewicz, Lublin 2013, col. 260-261. 
i daleki od człowieka ${ }^{12}$. Jednak nie zyskały one większego znaczenia, toteż nurtujące pytania nadal pozostają bez odpowiedzi.

\section{Hellenistyczne chrześcijaństwo i jego nihilizm}

Nietzsche w swej krytyce chrześcijaństwa oskarża je o to, iż przyczyniło się do uśmiercenia Boga. Pisze myśliciel: „Każdy kościół to kamień na grobie człowieka-boga, nie zezwala mu zmartwychwstać"13. Nietzsche postrzegał chrześcijaństwo jako skoncentrowane wyłącznie na tamtym świecie i łudzące człowieka obietnicami zaświatów. Pisze o chrześcijaństwie: „[...] «chrześcijaństwo», to znaczy zepsucie duszy pojęciem winy, kary i nieśmiertelności" ${ }^{14}$. Dlatego przeciwstawiał mu dionizyjską wolność ducha i umiłowanie życia na tym świecie, na ziemi, za wzór biorąc Dionizosa - boga wina. Pisał: „Przeciw moralności więc zwracał się wtedy [...] mój instynkt jako afirmujący instynkt życia i wynalazł sobie zasadniczo opozycyjną doktrynę i przeciwstawną ocenę życia, czysto artystyczną, antychrześcijańską [...] nazwałem ją dionizyjską [...]. Zrozumianoż mnie? - Dionizos przeciw Ukrzyżowanemu"15.

Wiedział jednak, że wraz z odrzuceniem chrześcijaństwa zanikną wartości, które ono ze sobą niosło i na których zbudowana została cywilizacja i kultura Europy. Dlatego jako jeden z pierwszych myślicieli dostrzegał nihilizm kryjący się za śmiercią Boga i zepsutym chrześcijaństwem. Pisał w Woli mocy: „To co opowiadam jest historyą dwóch najbliższych stuleci. Opisuję, co będzie, co inaczej już być nie może: pojawienie się nihilizmu. Tą historyę można opowiedzieć już teraz: albowiem konieczność sama jest tu przy robocie. Ta przyszłość mówi już setkami znaków, ten los zapowiada się wszędzie [...]"16.

12 Por. A. Morawska, Dietrich Bonhoeffer. Wybór pism, Warszawa 1970, s. 239.

13 Za: A. Camus, Człowiek zbuntowany, przeł. J. Guze, Warszawa 2002, s. 90.

14 F. Nietzsche, Antychryst, przeł. L. Staff, Kraków 2003, s. 61.

15 F. Nietzsche, Ecce homo..., dz. cyt., s. 80.

16 F. Nietzsche, Wola mocy. Próba przemiany wszystkich wartości, przeł. S. Frycz, K. Drzewiecki, Warszawa 1910-1911, s. 1. Nihilizm opisuje Nietzsche następująco: „Nihilizm: brak celu; brak 
Nietzsche uważał, że chrześcijaństwo, przenosząc środek ciężkości na Boga i zaświat, odwartościowało ten świat i życie na ziemi ${ }^{17}$. Dlatego ostrze swej krytyki skierowanej ku chrześcijaństwu wymierzył m.in. w ideę zaświatów. Jednak istotny jest fakt, że idea ta wywodzi się bardziej z myśli greckich orfików i Platona niż z Biblii. To orficy widzieli w ciele więzienie duszy, a Platon dowodził, że to świat idei jest rzeczywisty, natomiast obecny, ziemski świat jest tylko marnym jego odbiciem ${ }^{18}$. Zatem można powiedzieć, że ostrze Nietzschego w tej kwestii nie trafia w istotę chrześcijaństwa, lecz tylko odcina hellenistyczne narośle. Pisze Lew Szestow: „Nietzschemu wydawało się, że był zmuszony wyrzec się chrześcijaństwa, ale wątpliwe czy tak właśnie było: był zmuszony wyrzec się hellenistycznych elementów w chrześcijaństwie [...]. Nietzsche, jak wszystko na to wskazuje, pozostawał jedynie pierwszym zwiastunem nadchodzących wydarzeń. Wszystko wskazuje na to, że panowanie Sokratesa dobiega kresu, że ludzkość wyrzeknie się helleńskiego świata prawdy i dobra, i powróci do zapomnianego przez nią Boga"19.

Jak słusznie zauważał Nietzsche, wartości, jakie chrześcijaństwo proponowało ludziom, zaczęły tracić swą wartość, zaś rozwijająca się nauka szybko przekonała ludzi do przyjęcia pozytywistycznego, empirycznego, ewolucjonistycznego punktu widzenia i postawy utylitarnej ${ }^{20}$. A gdy statyczna, Arystotelesowska koncepcja Boga jako Pierwszego Poruszyciela zaczęła przeważać i ogłoszona została jako "naukowa koncepcja Boga”, wówczas paradoksalny Bóg Biblii odszedł w zapomnienie ${ }^{21}$. Wiara została ujęta w szereg definicji i sprowadzona do doktrynalnego wymiaru

odpowiedzi na pytanie dlaczego? - Co znaczy nihilizm? To, że najwyższe wartości tracą wartość" (F. Nietzsche, Wola mocy..., dz. cyt., s. 10).

17 Por. L. Łysień, Religia, ateizm, wiara. Problematyka filozofii Boga w XIX i XX wieku, Kraków 2004, s. 130.

18 Por. L. Łysień, Myślenie według Ewangelii, Kraków 2018, s. 323.

19 L. Szestow, Potestas clavium, dz. cyt., s. 31.

20 Por. L. Łysień, Religia, ateizm, wiara, dz. cyt., s. 134-135.

${ }^{21}$ Filozoficzna platońsko-arystotelesowska idea Boga jako Causa sui, Pierwszego Poruszyciela czy Najwyższej Idei złączona z obrazem Boga Biblii byłaby do przyjęcia tylko wówczas, gdyby takiemu połączeniu towarzyszyła nieustanna świadomość, że zarówno w opowieściach biblijnych, jak i w koncepcjach filozoficznych przekazywana jest prawda o Bogu w postaci dwóch nurtów metafor, 
credo - który stanowi wynik pracy rozumu ustanawiającego dogmaty. W cieniu pozostał wymiar wiary jako fides - pełnej ufności odpowiedzi człowieka na wezwanie Boga, wiary, która rozumie, iż Bóg jest zawsze większy od wszystkich Jego obrazów, jakie tworzy ludzki rozum ${ }^{22}$.

Tym samym najwyższe wartości, jakie były powszechnie uznawane, m.in. transcendentny sens świata oraz istnienie obiektywnych wartości, uległy deprecjacji ${ }^{23}$, a na gruzach dotychczasowej wizji świata pojawił się nihilizm, który Nietzsche jako pierwszy dostrzegł u wrót Euro$\mathrm{py}^{24}$. Niemiecki filozof twierdził, iż jest pierwszym zupełnym nihilistą w Europie ${ }^{25}$, który dzięki przemyśleniu nihilizmu do końca, może znaleźć sposób, aby go pokonać ${ }^{26}$. Pisze Albert Camus: „Nietzsche mówi o przyszłej apokalipsie nie po to, aby ją zachwalać - odgadywał bowiem jej twarz ponurą i wyrachowaną - ale żeby jej uniknąć i przekształcić ją w odrodzenie" ${ }^{27}$. Nietzsche zwraca tym uwagę na ważny aspekt, że nihilizm ma stanowić dla człowieka szansę, by przezwyciężając go, wreszcie zaczął afirmować życie i tworzył nowe wartości. Pisze Tomaś Halik: „Dopiero człowiek pozbawiony swoich pewności, wychylony ku nocy niebytu, skonfrontowany z Nic, może [...] odnaleźć sens"28. Bowiem dopóki człowiek nie odważy się skonfrontować z nicością, nihilizmem, nie będzie w stanie go przezwyciężyć i nadać swemu życiu sensu. Komentuje

które wzajemnie się objaśniają i korygują. Por. T. Halik, Wzywany czy niewzywany Bóg się tutaj zjawi, dz. cyt., s. 289.

22 Rozróżnienie wiary credo/fides por. L. Łysień, Przygody myślenia religijnego, Kraków 2016, s. 279. Pisze Halik: „Ojczysta mowa wiary nie jest językiem definicji i sylogizmów, wiara od początku wyrażana jest przez wydarzenia, przypowieści. Uwierzyć nie znaczy rozumem przytaknąć zbiorowi prawd, ale otworzyć na to wydarzenie przestrzeń swego życia, aby w niej mogło się rozwijać; «wejść w wydarzenie» i przyjąć jednocześnie owo wydarzenie jako klucz do rozumienia swego własnego życia, swego własnego losu" (T. Halik, Wzywany czy niewzywany Bóg się tutaj zjawi, dz. cyt., s. 94).

${ }^{23}$ Por. L. Łysień, Religia, ateizm, wiara, dz. cyt., s. 135.

24 Por. T. Halik, Co nie jest chwiejne, jest nietrwałe. Labiryntem świata $z$ wiara $i$ watpliwościami, przeł. J. Zychowicz, Kraków 2004, s. 62.

25 Por. F. Nietzsche, Wola mocy..., dz. cyt., s. 2.

${ }^{26}$ Por. K. Löwith, Od Hegla do Nietzschego..., dz. cyt., s. 237 oraz K. Jaspers, Rozum i egzystencja. Nietzsche a chrześcijaństwo, przeł. C. Piecuch, Warszawa 1991, s. 181.

27 A. Camus, Człowiek zbuntowany, dz. cyt., s. 86.

28 T. Halik, Co nie jest chwiejne, jest nietrwałe..., dz. cyt., s. 62. 
Grzegorz Sowiński: „[Nietzsche] Na powrót przypomina nam, że życie jest otoczone nicością. Która dziś popadła w zapomnienie. Odwrócono się od nicości. Bojkotuje się nicość. Dlatego człowiek pozostaje tylko człowiekiem. Dlatego nie wzlatuje już ponad «siebie». [...] Nihilizm przegrał całkowicie z pozytywizmem, to znaczy z życiem, które pazernie nastawia się na sferę dóbr pozytywnych" ${ }^{29}$. To bardzo ważna lekcja, jaką Nietzsche może dać współczesnemu człowiekowi, ale wydaje się, że nie jedyna.

\section{Resentyment i nadczłowiek}

Nietzsche wskazuje, że przenosząc akcent na tamten świat, chrześcijaństwo złamało człowieka, bowiem lekceważąc ziemię, zlekceważyło ziemski wymiar ludzkiego życia i ludzkie ciało. O chrześcijaństwie pisze on: „[...] chce złamać mocnych, zniechęcić do męstwa, wykorzystać ich złe godziny i znużenie, przemienić ich wyniosłą pewność w niepokój i zgryzotę sumienia, że szlachetne instynkty potrafi uczynić jadowitymi i chorymi, aż ich siła, ich wola mocy cofa się i zwraca przeciw sobie samej - aż ci mocni giną nie zachowując umiaru w pogardzie dla siebie i znęcaniu się nad sobą $[. .$.$] ”30. „Wiara chrześcijańska od początku$ oznacza poświęcenie: poświęcenie wszelkiej wolności, wszelkiej dumy, wszelkiej pewności ducha $[\ldots]^{\prime 31}$. Tymi słowami opisuje on resentyment, który zarzuca chrześcijaństwu, bowiem to z niego rodzi się skarlały człowiek. Stwierdza: „[...] spod najświętszych nazw wyciągnąłem niszczycielskie tendencye; nazywano Bogiem, co osłabia, co uczy słabości, słabością zaraża [...]" ${ }^{32}$. Nietzsche dostrzega, że duchowość stała się ociężała, zaś chrześcijaństwo religią posępną, nazbyt uroczystą, pełną swego rodzaju mrocznego napięcia.

\footnotetext{
29 G. Sowiński, Dlaczego lubię/nie lubię Nietzschego?, „Znak” 54 (2002) nr 567 (8), s. 87.

30 Za: K. Jaspers, Rozum i egzystencja..., dz. cyt., s. 201.

31 F. Nietzsche, Poza dobrem i złem, przeł. G. Sowiński, Kraków 2001, s. 70.

32 F. Nietzsche, Wola mocy..., dz. cyt., s. 93.
} 
Obraz chrześcijaństwa, jaki przedstawia Nietzsche, jest bez wątpienia karykaturą, jednak nie można zaprzeczyć jego istnieniu w świadomości osób wierzących ${ }^{33}$. To typ chrześcijaństwa najpowszechniejszy i popularny, który największe cnoty czyni z odrzucenia i pogardy oraz choruje na obsesję grzechu. Typ chrześcijaństwa, które rzuciło cień podejrzenia na wszystkie naturalne skłonności człowieka, fałszywie interpretując jego popędy i czyny, doszukując się w nich grzechu ${ }^{34}$. Bóg jawił się odtąd jako posępny podglądacz, który z uwagą śledzi wszystkie ludzkie występki. Człowiek, mając przed oczyma swą grzeszność i nikczemność, zaczął pogardzać sobą i pogrążać się we wspomnianym już resentymencie, wierze cierpiętniczej, zjadliwej, chorej, która z życia uczyniła piekło, zatruwając wszelką ziemską radośćc ${ }^{35}$. Wiara taka stała się świadomością nieszczęśliwą, która upatruje istotę relacji z Bogiem w nieszczęściu, ponieważ nieszczęście i cierpienie wzbudzić może w surowym i ponurym Bogu litość, która skłoni Go do użalenia się nad zabiedzonym wyznawcą. Tak powstaje błędne koło: nieszczęście generuje wiarę, która wymaga nieszczęścia ${ }^{36}$.

Wobec tak skarlałego chrześcijaństwa Nietzsche woła o człowieka wyższego, szlachetniejszego, a wołanie to wydaje się być w zaistniałych okolicznościach całkowicie zasadne. Pisze myśliciel: „Przezwyciężcie mi o ludzie wyżsi, te małe cnoty, małostkową roztropność, te pyłkowe względy, te rojenia się mrówcze, tę żałosną błogość, to «szczęście najliczniejszych»" ${ }^{37}$. Nietzsche przedstawia w tym miejscu ideę nadczłowieka, którego nadejścia oczekuje. Nadczłowiek będzie silny, dumny ze swej mocy, nieograniczony zakazami. Tak charakteryzuje go w dziele $Z$ genealogii moralności: „[...] wyzwalający człowiek wielkiej miłości i pogardy, duch twórczy, którego napór sił własnych ciągle wygania z wszelkich uboczy i zaświatów, którego samotności tłum nie rozumie,

33 Por. M. Neusch, U źródeł współczesnego ateizmu..., dz. cyt., s. 184.

34 Por. L. Kołakowski, Jeśli Boga nie ma, Kraków 1988, s. 217.

35 Por. Z. L. Łysień, Myślenie według Ewangelii, dz. cyt., s. 333.

${ }^{36}$ Por. J. Tischner, Spowiedź rewolucjonisty. Czytając „Fenomenologię ducha” Hegla, Kraków 2016, s. 99.

37 F. Nietzsche, Tako rzecze Zaratustra..., dz. cyt., s. 357. 
jak gdyby była ona ucieczką przed rzeczywistością: tymczasem jest ona tylko jego zanurzeniem się, zagrzebaniem, zagłębieniem w rzeczywistość, by stamtąd kiedyś, gdy znów wróci na światło, mógł wyzwolenie przynieść tej rzeczywistości: jej wyzwolenie od przekleństwa, którym obarczył ją dotychczasowy ideał. [...] ten dzwon bijący południa i wielkiego rozstrzygnięcia, dzwon, który wolę znów wolną uczyni, który wróci ziemi jej cel, a człowiekowi jego nadzieje, ten antychryst i antynihilista, ten zwycięzca Boga i nicości - przyjść kiedyś musi...”38.

Można zauważyć, że różnica, jaka zachodzi między człowiekiem nietzscheańskim a chrześcijaninem, to różnica w postawie wobec życia, odmienna jakość bytu ${ }^{39}$. Nadczłowiek stanowi nowe zadanie postawione człowiekowi: ma on akceptować siebie i posiadać siebie ${ }^{40}$. Co istotne, nie jest on wynikiem hodowli czy eugeniki, nie jest wyższym stopniem rozwoju ${ }^{41}$. Nietzsche stronił od interpretacji nadczłowieka jako typu biologicznego, choć byłaby ona zgodna $\mathrm{z}$ panującym wówczas darwinizmem ${ }^{42}$. Wolał zachować dystans wobec darwinizmu, a nawet dowodził, że częściej giną właśnie wybitne jednostki niż pośledniejsi przedstawiciele gatunku, którzy kierując się strachem, gromadzą się w grupy, zyskując dzięki temu potęgę ${ }^{43}$.

Jednak istotne jest, że nadczłowieka można interpretować nie jako bałwochwalcę oddającego cześć sobie, jak mogłoby wynikać z pobieżnej lektury pism Nietzschego ${ }^{44}$. Filozof negatywnie wypowiadał się na temat "samopodziwu i chamstwa”, które oglądał już za swego życia u Niemców szczycących się swą rasą. Tych Niemców, którzy w latach późniejszych z błędnej interpretacji jego pism czerpali swe natchnienia

38 F. Nietzsche, Z genealogii moralności. Pismo polemiczne, przeł. G. Sowiński, Kraków 2003, s. 71.

39 Por. M. Neusch, U źródeł współczesnego ateizmu..., dz. cyt., s. 155-156.

40 Por. M. Neusch, U źródeł współczesnego ateizmu..., dz. cyt., s. 154.

${ }^{41}$ Por. K. Michalski, Płomień wieczności. Eseje o myślach Fryderyka Nietzschego, Kraków 2007, s. 230.

42 Por. R. Safranski, Nietzsche. Biografia myśli, przeł. D. Stroińska, Warszawa 2003, s. 302.

43 Por. F. Copleston, Historia filozofii, t. 7, przeł. J. Łoziński, Warszawa 2006, s. 356.

44 Por. M. Neusch, U źródeł współczesnego ateizmu..., dz. cyt., s. 153. 
do tworzenia nazizmu i okryli jego filozofię cieniem swych zbrodni ${ }^{45}$. Dla Nietzschego bowiem to dostojność, nie tylko siła, stanowiła istotną cechę panów ${ }^{46}$. Nadczłowiek dzięki akceptacji siebie może uznawać również odmienność drugiego ${ }^{47}$. Dlatego termin „nadczłowiek” może być rozumiany nie jako odnoszący się do hierarchii, nie oznacza jakiegoś wyżej ${ }^{48}$, ale raczej ponad miarę, więcej. Pisze Jacek Filek: „Któż nie marzył, by żyć inaczej, bardziej otwarcie, swobodniej, bez lęku, bardziej wynioślej, lecz przecież nie wyniośle, lekko, lecz przecież nie lekkomyślnie? Tymczasem życie nasze, choć jest życiem w zaszczuciu, nadyma się jednak i popada nawet $\mathrm{w}$ zadowolenie. Zaratustra budzi uśpioną tęsknotę za «wyżynnym człowiekiem», za «czymś więcej» niż człowiek, ale takim "czymś więcej», czym sam miałbyś się uczynić, czym możesz się uczynić" ${ }^{\prime 9}$.

W tym znaczeniu idea ta może wpływać na ludzi czasów obecnych ${ }^{50}$. Szczególnie na mieszkańców rozwiniętej i cywilizowanej Europy, którzy zwątpili już w wolność osoby, śniąc o wolności gatunku, agonię zbiorową nazywają nieśmiertelnością i nie żyją teraźniejszością, ale wciąż upatrują świetlanej przyszłości, pomimo iż ta dość złośliwie opóźnia swe nadejście ${ }^{51}$. Wobec obecnie propagowanej przeciętności i obniżaniu standardów myśl Nietzschego może - paradoksalnie - przypomnieć

45 Por. M. Neusch, U źródeł współczesnego ateizmu..., dz. cyt., s. 154.

46 Por. W. Tatarkiewicz, Historia filozofii, t. 3, Warszawa 1998, s. 190.

47 Por. M. Neusch, U źródeł współczesnego ateizmu..., dz. cyt., s. 154.

48 Por. K. Michalski, Płomień wieczności..., dz. cyt., s. 231.

49 J. Filek, Dwie nauki: dwie miłości, dwie wieczności, „Znak” 54 (2002) nr 567 (8), s. 70.

50 Jedynie w tym znaczeniu, ponieważ nie można zapomnieć, że w opisanych przez Nietzschego przemianach tożsamość człowieka staje się kategorią bardzo kruchą i niestabilną. Jej znaczenie dopiero tworzy się w grze życia, w której wszystko stanowi stawkę, nawet człowieczeństwo. Nadczłowiek zdaje się bowiem posiadać naturę bardziej boską niż ludzką, a zatem naturę nie - ludzką. Nietzsche odrzuca rozdarcie, jakie istnieje w człowieku, gdy zmaga się on z własnym losem, a tym samym pozbawia człowieka cechy istotnie ludzkiej. Również zgoda na wszystko może mieć niebezpieczne konsekwencje. Pisze Camus: „Powiedzieć «tak» wszystkiemu oznacza powiedzieć «tak» zabójstwu” (A. Camus, Człowiek zbuntowany, dz. cyt., s. 98).

${ }^{51}$ O sytuacji tej celnie pisze Camus: „Europa przestała kochać życie, oto jej tajemnica” (A. Camus, Człowiek zbuntowany, dz. cyt., s. 352). 
istotne przesłanie chrześcijaństwa, które zdawał się odczytywać niezwykle przenikliwie, pisząc o Chrystusie: „Nikogo nie oceniał nisko” ${ }^{2}$.

\section{4. Życie nietzscheańskie/chrześcijańskie}

Myśl Nietzschego może na nowo przywołać prawdę, że spojrzenie ewangeliczne to takie, które zawsze widzi głębiej, szerzej, więcej, które sięga do głębi istoty człowieka, by go podźwignąć. Ewangelia bowiem wzywa człowieka do wyjścia z bylejakości, wytrąca z ospałości, niepokoi, daje do myślenia. Nie pozwala na to, by człowiek pozostał na poziomie zwierzęcego zadowolenia, stawia przed nim wyzwania i prowokuje, zaprasza, by je podjąć, by zacząć naprawdę żyć - prawdziwie, w pełni ${ }^{53}$. Zaprasza do tego, by nie zabezpieczać swego życia za wszelką cenę, podejmować ryzyko, stworzyć otwartą przestrzeń wokół siebie, w której może pojawić się to, co niespodziewane, by pozwolić być drugiemu człowiekowi, światu, a nade wszystko Bogu, nie przykrawać wszystkiego do miary własnego rozumu ${ }^{54}$.

Warto zauważyć, że cecha ta stanowi postawę zarówno nietzscheańskiego $^{55}$, jak i ewangelicznego dziecka, które Chrystus stawia uczniom

52 Za: L. Łysień, Myślenie według Ewangelii, dz. cyt., s. 223.

53 Por. L. Łysień, Myślenie według Ewangelii, dz. cyt., s. 277.

54 Por. L. Łysień, Myślenie wedtug Ewangelii, dz. cyt., s. 127-128, 244.

55 Nietzsche w Tako rzecze Zaratustra opisuje proces przemian ducha człowieka, który powinien zaistnieć w drodze ku nadczłowiekowi: „Nazwę wam trzy przemiany ducha: jak duch wielbłądem się staje, wielbłąd lwem; wreszcie lew dziecięciem" (F. Nietzsche, Tako rzecze Zaratustra..., dz. cyt., s. 25). Wielbłąd, symbol człowieka wielbiącego, skłania się przed Bogiem i prawem moralnym, a z czasem przed wartościami naukowymi, gdy nauka zajmuje miejsce religii. Zawołanie owego człowieka to: musisz, powinieneś. W następnej kolejności wielbłąd zostaje lwem, który woła już „ja chcę”. Dopiero człowiek, którego symbolizuje lew, jest w stanie przeciwstawić się dotychczasowym wartościom i już ich nie wielbić, ale wręcz je burzyć. To jednak nie wystarcza, gdyż lew musi przemienić się w dziecię: „Lecz powiedzcie mi, bracia, cóż zdoła dziecię, gdzie lew nawet nie podoła? Czemu lew drapieżny dziecięciem stać się jeszcze winien? Niewinnością jest dziecię i zapomnieniem, jest nowopoczęciem, jest grą, jest toczącym się pierścieniem, pierwszym ruchem, świętego «tak» mówieniem. O tak, do gry tworzenia, bracia moi, należy i święte «tak» nauczyć się wymawiać: swojej woli pożąda duch, swój świat odnajduje, kto się w świecie zatracił" (F. Nietzsche, Tako rzecze Zaratustra..., dz. cyt., s. 27). 
za wzór ${ }^{56}$. Pisze Leszek Łysień: „Dziecko ewangeliczne Ewangelię przyjmuję nie dlatego, że jest miła, przytulna, swojska, ale dlatego, że jest dziwna, paradoksalna, z punktu widzenia dorosłych zbyt szalona i pozbawiona braku ekonomicznej i politycznej powagi" ${ }^{57}$. Jak zauważa polski myśliciel Karol Ludwig Koniński, w ogóle religia nie ma uspokajać człowieka, zapewniając go, że wszystko jest właściwie urządzone, a jego żywot zabezpieczony. Religia winna raczej dawać życiu polot, bogactwo, pełnię, ma przepajać życie człowieka blaskiem mistycyzmu i uzdalniać go do wzniesienia się ponad nijakość i przeciętność; do heroizacji swego życia ${ }^{58}$.

Nietzsche swym wołaniem również zwraca uwagę na fakt, że przyszłość zarówno ziemska, jak i pośmiertna rozgrywa się tu na ziemi w teraźniejszości życia. Idea wiecznego powrotu tego samego, którą głosił, pomimo wszystkich swych zawiłości i wątpliwości, jakie może budzić, bez wątpienia stanowi niezwykłą świadomość - ewangeliczną niemal ważności każdej chwili życia ${ }^{59}$. Bowiem to właśnie chwila - nie rok, nie dzień, nie godzina - ale chwila, winna być przeżywana do głębi, z całą intensywnością, natężeniem zmysłów. A człowiek nie powinien żyć bezmyślnie, bo choć takie życie kusi splendorem, oszałamia blaskiem halogenowych świateł i obiecuje wygodę i spokój, daje w istocie jedynie marną, pustą egzystencję, która mieni się sztucznymi barwami podszytymi nijakością. Myśl Nietzschego może zatem pomóc człowiekowi zdystansować się od niepoddanego refleksji, spłyconego świata, upiornych miast

56 Por. L. Łysień, Religia, ateizm, wiara, dz. cyt., s. 144.

57 L. Łysień, Myślenie według Ewangelii, dz. cyt., s. 128.

58 Por. L. Łysień, Przygody myślenia religijnego, dz. cyt., s. 165, 255.

59 Idea ta, której podobne rozumienie Nietzsche odnalazł u Heraklita, zgodna jest $\mathrm{z}$ koncepcją poznania, jaką przyjął. We Wszechświecie istnieje przecież nieubłagany „chaos konieczności”, w którym nie ma statycznego bytu, ale tylko nieustanne stawanie się. A ponieważ świat nie może stawać się w nieskończoność, w bardzo dużych odstępach czasu wszystko będzie powracać, bowiem nieskończony jest czas istnienia świata. Nietzsche pragnie odkryć jedność czasu, chce pojednać przyszłość z przeszłością. Każda chwila łączy w sobie czas i wieczność, wiecznie powracając. Jednak czas, o jakim mówi Nietzsche, to nie jedynie czas fizyczny. Jest to bowiem czas, jaki wyznaczają powracające czyny woli. Por. F. Nietzsche, Ecce homo..., dz. cyt., s. 55 oraz interpretacje, np.: K. Jaspers, Nietzsche, przeł. D. Stroińska, Warszawa 1997, s. 276; K. Löwith, Od Hegla do Nietzschego..., dz. cyt., s. 448 . 
przesiąkniętych konwencjonalizmem, ludzkiej fascynacji pozorem i tanim blaskiem, które tłamszą człowieka, czynią go ociężałym i ograniczając jego widzenie, sprawiają, że ludzie po dwóch wiekach chrześcijaństwa nie potrafią już wyobrazić sobie Chrystusa radosnego, śmiejącego się.

\section{Zakończenie}

W dziełach Nietzschego próżno szukać gotowych odpowiedzi. Jego myśl stanowi bardziej ruch myślenia - jak pisał Karl Jaspers - który otwiera przestrzeń, umożliwia coś nieznanego, co dopiero nadejdzie. Jest to myślenie wichrzące, które kieruje ku czemuś, rozsadza utarte schematy, jest ciągle w drodze. I w tej wędrówce spotyka ono chrześcijaństwo, które również winno być nieustannie $\mathrm{w}$ drodze.

Oczywiście Nietzsche celowo nie bronił prawdziwego chrześcijaństwa w wymiarze Dobrej Nowiny. W licznych dziełach poświęconych jego myśli można znaleźć wiele argumentów przemawiających za tym, że był on zagorzałym wrogiem religii pragnącym zniszczenia chrześcijaństwa ${ }^{60}$. Interpretatorzy jego dzieł wskazują na pogardę, jaką żywił do zwykłych, słabych ludzi ${ }^{61}$. Ważny wątek $\mathrm{w}$ tym nurcie interpretacji stanowi również Nietzscheańska relatywizacja prawdy, tzn. głoszenie braku prawdy obiektywnej, a tym samym używanie formuły „poza dobrem i złem” wskazującej na brak jakichkolwiek norm możliwości oceniania ludzkiego czynu ${ }^{62}$. Bez wątpienia są to interpretacje ważne i zasadne. Należy jednak pamiętać, że recepcja myśli Nietzscheańskiej jest ambiwalentna i bogata ${ }^{63}$, a owocem tego są interpretacje często ze sobą sprzeczne ${ }^{64}$. Zauważa Rüdiger Safranski: „Nietzsche aranżuje więc swoje książki tak, byśmy w poszukiwaniu myśli przewodniej, natrafili w najlepszym

60 Por. Dlaczego lubię/nie lubię Nietzschego?, różni autorzy, dz. cyt., s. 71-94.

61 Zob. L. Kołakowski, Po co Nietzsche? Debata, „Gazeta Wyborcza” nr 132, 6.06.1998, s. 22.

${ }^{62}$ Por. Żadło Nietzschego. Z Jackiem Filkiem, Krzysztofem Michalskim i Karolem Tarnowskim rozmawia Łukasz Tischner, „Znak” 54 (2002) nr 567 (8), s. 13-28; K. Tarnowski, Uczciwie wobec ateizmu, „Znak” 2013 nr 700 (9), s. 17.

63 Por. K. Michalski, Żądło Nietzschego, dz. cyt., s. 15.

64 Por. T. Halik, Radziłem się dróg, przeł. J. Babuchowski, Poznań 2001, s. 436. 
wypadku na własne myśli. Nie jest takie ważne, czy odkryjemy przy tym jego, Nietzschego; większe znaczenie ma to, czy odkryjemy myślenie" ${ }^{65}$. Dlatego niniejszy artykuł stanowi głos w dyskusji toczącej się na temat myśli Nietzscheańskiej. Nie można bowiem przeoczyć, że wymiar prawdziwego chrześcijaństwa fascynował Nietzschego ${ }^{66}$. Wiele swych myśli notował w przeciwstawieniu bądź odniesieniu do chrześcijaństwa ${ }^{67}$, budował swego Zaratustrę nie tylko w opozycji wobec chrześcijaństwa, ale i na podobieństwach ${ }^{68}$. Pisze Charles Taylor: „[Nietzsche] uchwytuje to, co jest kwestią centralną dla judaizmu i chrześcijaństwa. I ratuje ją od zapomnienia"69. Przedstawione analizy wskazują, że możliwa i zasadna jest interpretacja myśli Nietzschego jako mającej pozytywne implikacje dla chrześcijaństwa, szczególnie czasów obecnych.

Myślenie Nietzschego nie boi się bowiem nocy, w której świat wydaje się być nieprzewidywalny, niepodatny na pragmatyczne kalkulacje ludzkiego rozumu. Noc ujawnia otchłanność świata, w której głębię chce sięgnąć Nietzsche - zbliżając się tym do Ewangelii, której narracja wkracza w noc, jej głębię, niedostępność dla rozumu pragmatycznego, tajemniczość ${ }^{70}$. Za dnia być może widzi się szerzej, jednak to w nocy widzi się głębiej. Dlatego śmierć Boga może być szansą, by Idol został zastąpiony Ikoną - obrazem Boga, który nie zatrzyma na sobie ludzkiego spojrzenia, a raczej poszerzy je i będzie wciąż odsyłać ku niewidzialnemu, nie pozwalając, by Tajemnica stała się problemem, z którym musi zmierzyć się ludzki rozum. Wszak Bóg nie jest problemem dla rozumu, lecz tajemnicą, której ów rozum winien dać się porwać ${ }^{71}$. Ale

65 R. Safranski, Nietzsche. Biografia myśli, dz. cyt., s. 269. Podobnie pisze Heidegger: „Szacunek dla jakiegoś myśliciela okazujemy jedynie wówczas, kiedy sami myślimy. To zaś nakazuje myśleć wszystko istotne, co pomyślane jest w jego myślach” (M. Heidegger, Powiedzenie Nietzschego „Bóg umart", w: M. Heidegger, Drogi lasu, Warszawa 1997, s. 206).

66 Por. Oby wszyscy tak milczeli o Bogu. Z ks. Józefem Tischnerem rozmawia Anna KarońOkońska, Kraków 2015, s. 211.

67 Por. M. Neusch, U źródeł współczesnego ateizmu..., dz. cyt., s. 136-137.

68 Por. J. Filek, Dwie nauki: dwie miłości, dwie wieczności, dz. cyt., s. 45-70.

69 Ch. Taylor, Dlaczego lubię/nie lubię Nietzschego, dz. cyt., s. 93.

70 Por. L. Łysień, Myślenie według Ewangelii, dz. cyt., s. 242.

71 Por. L. Łysień, Religia, ateizm, wiara, dz. cyt., s. 291-292. 
tylko po przejściu przez noc możliwe będzie odkrycie na nowo prawdziwego Boga zmartwychwstania, pocieszenia i Pantokratora ${ }^{72}$. Boga, o którym jedynie wiara może dać świadectwo, a nie rozumowe spekula$\mathrm{cje}^{73}$. Chrześcijanin spoglądający w otchłanność nocy świata odnajdzie tam, być może, Boga, za którym tęsknił Nietzsche, i - wzorem ucznia, jakiego niemiecki filozof sobie życzył - pójdzie dalej drogą, przed którą Nietzsche się zatrzymał - drogą Miłości. Bowiem tylko Miłość daje życie, pozwala żyć w pełni, tylko ona jest twórcza. Kto kocha, nie może liczyć na spokojną egzystencję w usypiającym dobrobycie i poczuciu sytości. Kto kocha, zbliża się do tajemnicy życia par excellence, która zawsze rozsadza sztywne i spróchniałe schematy myślowe i wymyka się kalkulującemu rozumowi.

Dlatego myśl Nietzschego może wnieść ożywczy powiew w wiele schematów i stereotypów, w których zdarza się zastygać chrześcijanom w swej bezmyślności. Prowokuje ona do refleksji nad własną wiarą i nad tym, czy deklarowane wyznania przekładają się na życie. Na gruzach martwych obrazów-karykatur Boga wskazuje ona i otwiera nowe sposoby postrzegania Tego, który jest Życiem. Może ona zatem, do pewnego stopnia, stanowić strumień, który oczyszcza chrześcijaństwo i kieruje je ku źródłom ewangelicznym, pomagając poszukiwać tropów Boga w ciemności nocy świata ${ }^{74}$.

\section{Bibliografia}

Ankieta: Dlaczego lubię/nie lubię Nietzschego, „Znak” 54 (2002) nr 567 (8), s. 71-94.

Banasiak B., Problemat Nietzschego, w: G. Deleuze, Nietzsche i filozofia, przeł. B. Banasiak, Warszawa 1993, s. 209-213.

Bierdiajew M., O przeznaczeniu człowieka, przeł. H. Paprocki, W. Polanowski, Kęty 2006. Camus A., Człowiek zbuntowany, przeł. J. Guze, Warszawa 2002.

\footnotetext{
72 Por. P. Ricoeur, Egzystencja i hermeneutyka. Rozprawy o metodzie, Warszawa 1975, s. 289.

73 Por. L. Łysień, Religia, ateizm, wiara, dz. cyt., s. 235.

74 Por. L. Łysień, Myślenie według Ewangelii, dz. cyt., s. 246.
} 
Chirpaz F., Sprzeczność posttotalitarnego czasu, przeł. M. Chłopecki, „Znak” 45 (1993) nr 458 (7), s. 133-139.

Copleston F., Historia filozofii, t. 7, przeł. J. Łoziński, Warszawa 2006.

Deleuze G., Nietzsche i filozofia, przeł. B. Banasiak, Warszawa 1993.

Filek J., Dwie nauki: dwie miłości, dwie wieczności, „Znak” 54 (2002) nr 567 (8), s. 45-70.

Graczyk P., Nietzsche a chrześcijaństwo, „Znak” 54 (2002) nr 567 (8), s. 29-44.

Halik T., Cierpliwość wobec Boga. Spotkanie wiary z niewiarą, przeł. A. Babuchowski, Kraków 2011.

Halik T., Co nie jest chwiejne, jest nietrwałe. Labiryntem świata z wiarq i wątpliwościami, przeł. J. Zychowicz, Kraków 2004.

Halik T., Radziłem się dróg, przeł. J. Babuchowski, Poznań 2001.

Halik T., Wzywany czy niewzywany Bóg się tutaj zjawi, przeł. A. Babuchowski, Kraków 2006.

Heidegger M., Drogi lasu, Warszawa 1997.

Janowski P., Nietzsche, w: Encyklopedia katolicka, t. 13, red. E. Gigilewicz, Lublin 2009.

Janowski P., Nietzscheanizm, w: Encyklopedia katolicka, t. 13, red. E. Gigilewicz, Lublin 2009.

Jaspers K., Nietzsche, przeł. D. Stroińska, Warszawa 1997.

Jaspers K., Rozum i egzystencja. Nietzsche a chrześcijaństwo, przeł. C. Piecuch, Warszawa 1991.

Kołakowski L., Jeśli Boga nie ma, Kraków 1988.

Löwith K., Od Hegla do Nietzschego. Rewolucyjny przełom w myśli XIX wieku, przeł.

S. Gromadzki, Warszawa 2001.

Łysień L., Myślenie według Ewangelii, Kraków 2018.

Łysień L., Przygody myślenia religijnego, Kraków 2016.

Łysień L., Religia, ateizm, wiara. Problematyka filozofii Boga w XIX i XX wieku, Kraków 2004.

Michalski K., Płomień wieczności. Eseje o myślach Fryderyka Nietzschego, Kraków 2007.

Morawska A., Dietrich Bonhoeffer. Wybór pism, Warszawa 1970.

Neusch M., U źródeł współczesnego ateizmu. Sto lat dyskusji na temat Boga, przeł.

A. Turowiczowa, Paris 1980.

Nietzsche F., Antychryst, przeł. L. Staff, Kraków 2003.

Nietzsche F., Ecce homo. Jak stajemy się tym, czym jesteśmy, przeł. L. Staff, Kraków 2003.

Nietzsche F., Poza dobrem i złem, przeł. G. Sowiński, Kraków 2001. 
Nietzsche F., Tako rzecze Zaratustra. Książka dla wszystkich i dla nikogo, przeł. W. Beret, Warszawa 1990.

Nietzsche F., Wiedza radosna, przeł. L. Staff, Kraków 2003.

Nietzsche F., Wola mocy. Próba przemiany wszystkich wartości, przeł. S. Frycz, K. Drzewiecki, Warszawa 1910-1911.

Nietzsche F., Z genealogii moralności. Pismo polemiczne, przeł. G. Sowiński, Kraków 2003. Oby wszyscy tak milczeli o Bogu. Z ks. Józefem Tischnerem rozmawia Anna KarońOkońska, Kraków 2015.

Po co Nietzsche? Debata, „Gazeta Wyborcza” nr 132, 6.06.1998, s. 22.

Ricoeur P., Egzystencja i hermeneutyka. Rozprawy o metodzie, przeł. E. Bieńkowska, Warszawa 1975.

Safranski R., Nietzsche. Biografia myśli, przeł. D. Stroińska, Warszawa 2003.

Sokołowski P., Śmierć Boga Teologia, w: Encyklopedia katolicka, t. 19, red. E. Gigilewicz, Lublin 2013.

Szestow L., Potestas clavium, przeł. J. Chmielewski, Kęty 2005.

Tarnowski K., Uczciwie wobec ateizmu, „Znak” 2013 nr 700 (9), s. 14-22.

Tatarkiewicz W., Historia filozofii, t. 3, Warszawa 1998.

Tischner J., Idąc przez puste błonia, Kraków 2005.

Tischner J., Spowiedź rewolucjonisty. Czytając „Fenomenologię ducha” Hegla, Kraków 2016. Żadło Nietzschego. Z Jackiem Filkiem, Krzysztofem Michalskim i Karolem Tarnowskim rozmawia Łukasz Tischner, „Znak” 54 (2002) nr 567 (8), s. 13-28.

\section{Abstrakt}

\section{Pozytywne implikacje myśli Fryderyka Nietzschego dla chrześcijaństwa post mortem Dei. Próba analizy}

Artykuł bada, czy Nietzsche, niewątpliwie przeciwny chrześcijaństwu, które widział, jest także daleki od sedna chrześcijaństwa i wiary ewangelicznej. Czy jego koncepcje mogą być wskazówką dla człowieka próbującego znaleźć ślady Boga w czasie post mortem Dei? Przy próbie odpowiedzi na powyższe pytania pomocna będzie analiza dzieł Nietzschego.

Na zakończenie artykuł wykaże, że burzliwe, niespokojne, otwarte, odważne i wciąż łamiące zwykłe myślenie Nietzschego, które nie boi się nocy, może stać się rodzajem 
szlaku w poszukiwaniu Boga, którego nie można uchwycić w siatkę pojęć. Może ono także stanowić strumień oczyszczający chrześcijaństwo i kierujący je z powrotem ku źródłom ewangelicznym. Może również pomóc chrześcijanom zastanowić się nad własną wiarą.

\section{Słowa kluczowe}

Nietzsche, chrześcijaństwo, śmierć, Bóg, noc

\section{Abstract \\ The Positive Implications of Fryderyk Nietzsche's Thought for Post Mortem Dei Christianity. An Attempt to Analyze}

The article examines whether Nietzsche - who was against the Christianity he saw is just as far from the heart of Christianity and the Gospel faith? And whether his concepts can be helpful for a man seeking God's footsteps in post mortem Dei time? Analysis the works of Nietzsche will be helpful when trying to answer the these questions.

In conclusion the article will show that restless, open, courageous and still breaking the usual patterns Nietzsche's thinking which is not afraid of the night, it may become a trail in search of the God, which can not be grasped in the concepts. And it can be a stream purifying Christianity, directing it back to the Gospel sources. And Nietzsche's thoughts can be helpful for Christians too, to they reflect on their faith.

\section{Keywords}

Nietzsche, Christianity, death, God, night 